\title{
PASSIFLORA FORMOSA SP. NOV., A HITHERTO MISUNDERSTOOD TAXON IN PASSIFLORA SUBGENUS TACSONIA (PASSIFLORACEAE) FROM COLOMBIA
}

\author{
T. ULMER*
}

\begin{abstract}
A new species of Passiflora is described from the Andes of Colombia. Passiflora formosa $\mathrm{T}$. Ulmer is characterized by its densely tomentose ovary, the 5-7 petiolar glands and the large leaves which are up to $19 \mathrm{~cm}$ long. It most closely resembles $P$. lanata and $P$. cuatrecasasii. The differences between these species are discussed.
\end{abstract}

Kelurds. Colombian flora, new species, vine.

\section{INTRODUCTION}

During the studies on the morphology and taxonomy of Passiflora L. subgenus Tacsonia (Juss.) Triana \& Planch., several specimens of critical species complexes were examined. Some specimens previously identified as Passiflora lanata (Juss.) Poir. were found to differ from the typical form of that species. A collection (Uribe 5945) from the Department Boyacá was first identified by the collector as $P$. cuatrecasasii Killip. Escobar re-identified the material and assigned this specimen to $P$. lanata, but pointed out that this plant differed in the density of indument, the leaf size and the length of peduncles noting that the specimen was somewhat extraordinary within the species (Escobar, 1988).

A re-examination of the specimen and further material in this complex revealed that the plant 5945 collected by Uribe differs from both $P$. cuatrecasasii and $P$. lanata in many points and should be regarded as an independent species. The species in question might be of hybrid origin from both species, but this is unlikely, because $P$. cuatrecasasii is not known from the Department Boyacá. A further collection (Uribe 1061, US) from Boyacá, which was placed in P. cuatrecasasii by Killip (1960) and $P$. lanata by Escobar (not mentioned in Escobar, 1988), might also belong to $P$. formosa. However, there are small differences in the form of the leaves and in the number of petiolar glands between both plants. Thus it must be examined in the field, whether this specimen belongs to Passiflora formosa. 


\section{THE NEW SPECIES}

Passiflora formosa T. Ulmer, sp. nov.

Type: Colombia, Department Boyacá: carretera de Virolín, entre Duitama y Charalá, kilometro 35, en el bosque, 3100m, 2 ix 1967, L. Uribe Uribe 5945 (holo. US-2596373: isotypes COL, MO, US-2741317).

Planta scandens; stipulae lineares $0.6 \quad 0.9 \mathrm{~cm}$ longae; petioli sub apice cum 5.7 glandulis; folia coriacea, lanceolata, $8.719 .1 \mathrm{~cm}$ longa, apice acuta, serrulata, subtus

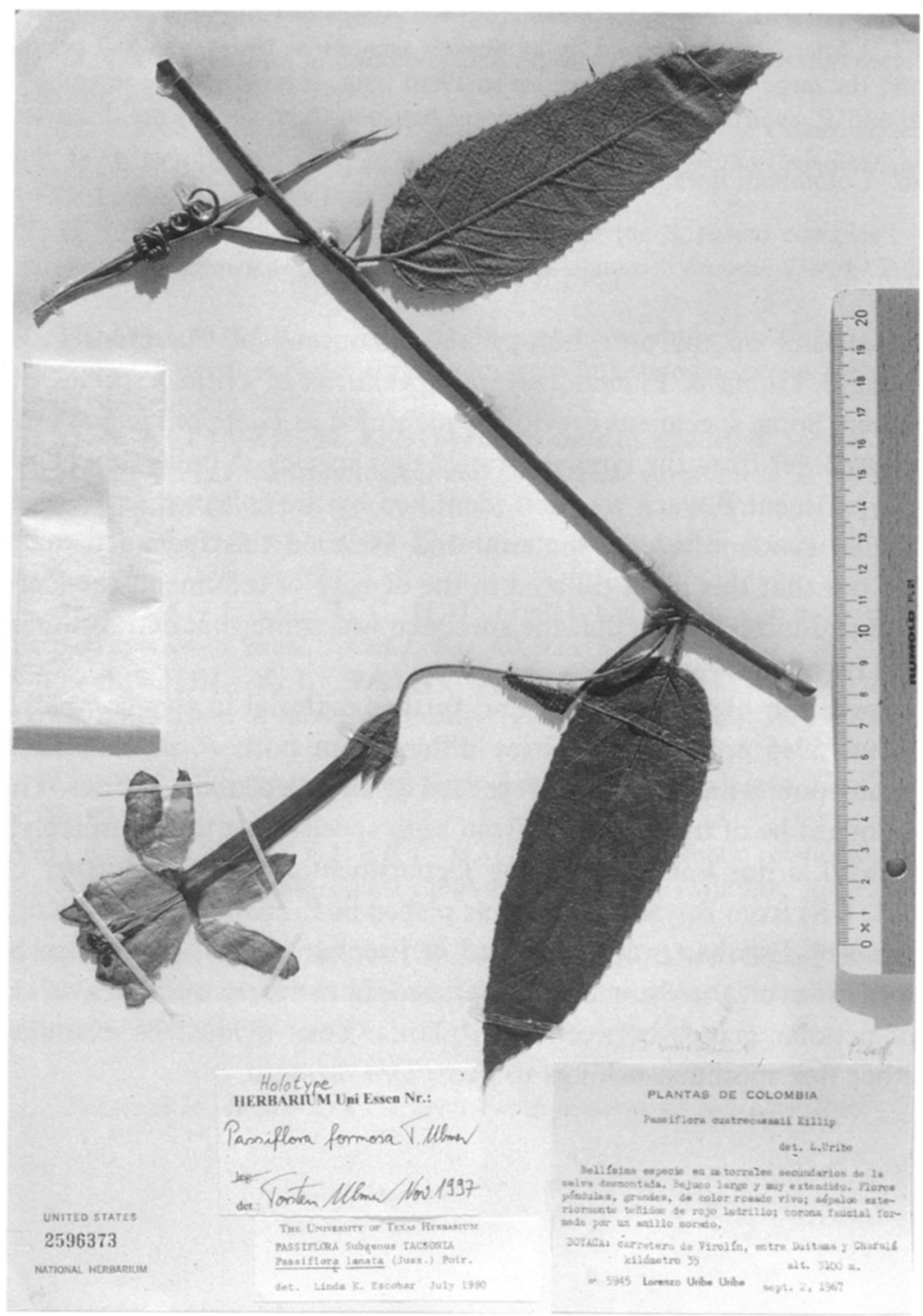

FIG. 1. Holotype of Passiflora formosa T. Llmer (Uribe 5945), deposited at US, 
obtecta indumento denso; pedunculi singulares, $8.5-11 \mathrm{~cm}$ longi; bracteae librae, lanceolatae, $2.6-3.2 \mathrm{~cm}$ longae; floral tubus (hypanthium) cylindricus glaber; sepala oblonga, obtusa $3.84 .6 \mathrm{~cm}$ longa; petalo sepalis subaequalibus; corona annularis undulata: ovarium tomento-sum. Ab speciebus $P$. cuatrecasasii et $P$. lanata petiolis 5-7 glandulosis, foliis $8.719 .1 \mathrm{~cm}$ longis, margine bracteorum integra et ovario tomentoso differens.

Vine, densely felty except for upper leaf surface, stipules and most parts of the flowers: stem terete to subangular, striate, younger parts denscly felty (villous): stipules linear, $0.6-0.9 \mathrm{~cm}$ long, blackish when dry, glabrous, margin entire: petiole $1.1-1.7 \mathrm{~cm}$ long with $5-7$ blackish, subsessile glands in the upper half of the petiole, often covered by the indument; leaves entire, lanceolate. $(8.7-) 10.5-14.9(19.1) \mathrm{cm}$ long, $2.85 .3 \mathrm{~cm}$ wide, acute at apex, base truncate to slightly cordate, glabrous and rugose on upper surface, the nerves impressed, densely felty (villous) underneath with pale brown to beige trichomes, slightly revolute at margin, serrate, thickcoriaceous: peduncles $8.5-11 \mathrm{~cm}$ long, solitary, pendent; bracts free to base, lanceolate, $2.63 .2 \mathrm{~cm}$ long, $0.50 .7 \mathrm{~cm}$ wide, acute at apex, felty, margin entire, borne about $1 \mathrm{~cm}$ below base of flower. Flowers $12.5-14 \mathrm{~cm}$ long, $9-10 \mathrm{~cm}$ in diameter, pinkish to pale purple: floral tube (hypanthium) cylindrical, $8.5-9 \mathrm{~cm}$ long, $0.7-1 \mathrm{~cm}$ wide (pressed), slightly dilated at base, glabrous; sepals oblong, glabrous, $3.8-4.6 \mathrm{~cm}$ long, $1.41 .9 \mathrm{~cm}$ wide, obtuse, aristate, awn about $0.2 \mathrm{~cm}$ long, pinkish to pale purple; petals subequal to sepals, pinkish to pale purple; corona uniserate, reduced to a slightly denticulate, dark ring at the apex of the floral tube; androgynophore 10.3-11 cm long: ovary ovoid to ellipsoid, densely tomentose with brownish trichomes; fruit unknown.

\section{TAXONOMIC REMARKS}

Passiflora fomosa belongs to the sect. Colombiana Escobar, ser. Colombianae Escobar which includes nine species (Escobar, 1988). These are spread over the Cordillera Oriental in Colombia. Two of them are also known from the west of Venezuela. The members of this series are recognized by the mostly unlobed, rugose leaves, the short petioles, the linear to lanceolate stipules, the comparatively short peduncles and the bracts, which are mostly free to the base.

Passiftora formosa is closely related to $P$. lanata and $P$. cuatrecasasii. It differs from $P$. lanata by having 57 petiole glands, a densely tomentose ovary, larger dimensions of leaves and flowers, longer peduncles and a less dense indumentum.

From $P$. cuatrecasasii the new species can be distinguished by its smaller bracts with an cntire margin, more glands at the petiole, the colour of the stipules and much longer lanceolate leaves with a felty indument underneath. The differences of the three species are summarized in Table 1.

Passiffora formosa is known only from the type collection in the Andes of Colombia at $3100 \mathrm{~m}$ elevation.

Etymology: The epithet refers to the statement of Uribe who found the plant 
TABLE 1. Comparison of Passiflora formosa and its closest relatives

\begin{tabular}{llll}
\hline \hline Characteristics & $P$. cuatrecasasii & $P$. formosa & P. lonata \\
\hline Petiolar glands & $2-3(5)$ & 5.7 & $2-4$ \\
Leaf size $(\mathrm{cm})$ & $38 \times 2.5-5.2$ & $10.5-19 \times 2.85 .3$ & $5-12 \times 2.7-6$ \\
Lower leaf surface & Densely pubescent & Felty & Densely lanate \\
Length of peduncle $(\mathrm{cm})$ & $(3.8) 7-10.5$. & $8.5-11$ & $2.2 .6(8)$ \\
Margin of bracts & Serrate & Entire & Entire \\
Length of sepals $(\mathrm{cm})$ & $3-5$ & 3.84 .6 & $2.3-3.5$ \\
Ovary & Densely tomentose & Densely tomentose & Glabrous \\
\hline
\end{tabular}

growing between Duitama and Charalá along the road to Virolin. He reported it to be a very beautiful species.

\section{ACKNOWLEDGEMENTS}

I wish to thank the curators of the herbaria AAU, COL, G, GOE, M, MO, MSB. US and USM for sending me material for examination on loan. Prof. Dr G.B. Feige kindly instructed my studies at the University of Essen. I'm grateful to Dr H.T. Lumbsch (Essen) for constructive criticism on this manuscript and Dr M. Jensen (Essen) for taking the habit photographs. The Latin description was kindly checked by Dr H. Kutzelnigg (Essen).

Finally I wish to thank Dr M. Schwerdtfeger (Göttingen) and Dipl.-Ing. K. Freudenreich (Stockholm) for their statements, as well.

\section{REFERENCES}

ESCOBAR. L. K. (1988). Passifloraceae. Passiflora. Subgeneros: Tacsonia. Rathea. Manicata y Distephana. In: PINTO. P. \& LOZANO, G. (eds) Flora de Colombia 10: $1-139$.

KILLIP, E. P. (1960). Supplemental notes on the American species of Passifloraceae with descriptions of new species. Contr. U.S. Natl. Herb. 35: 1-23.

Received 10 March 1998; accepted with revision 23 November 1998 